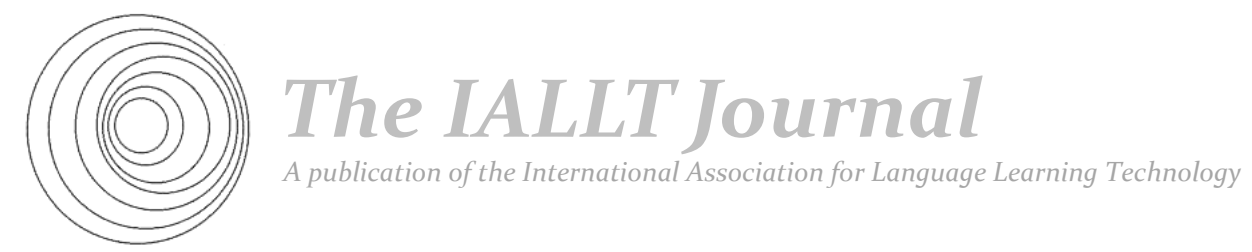

\title{
THE EFFECTS OF ASYNCHRONOUS COMPUTER VOICE CONFERENCING ON L2 LEARNERS’ SPEAKING ANXIETY
}

\author{
María Isabel Charle Poza \\ Lincoln University
}

\begin{abstract}
This study investigated the influence of a computer voice conferencing environment (Wimba) on learners' anxiety when speaking in a foreign language. Several instruments were used for data collection: A demographic survey, the Computer Anxiety Index (CAIN), the Foreign Language Classroom Anxiety Scale (FLCAS), the Wimba Anxiety Scale, student interviews, and a rubric developed for the evaluation of risktaking. Results indicate that there is a strong potential for the reduction of anxiety associated with the Wimba environment. This was due to the elimination of the time pressure of the classroom and opportunity to edit student contributions. Increased risk-taking, in terms of the quantity and quality of the output produced by students, and reduced fear of negative evaluation were also found in the electronic environment. The conditions of the facility where the Wimba environment is accessed, i.e. a language laboratory, were found to hinder Wimba's anxiety-reducing potential.
\end{abstract}

\section{INTRODUCTION}

The development of speaking proficiency is a significant goal for foreign language (L2) teachers and scholars and is also highly valued by learners, either because of personal satisfaction or career interests (Omaggio Hadley, 2001). Omaggio Hadley (2001) also points out that it is the task of L2teachers to identify effective strategies for teaching oral skills and to increase the opportunities for developing oral 
proficiency; however, foreign language educators often experience difficulties in encouraging all students to participate openly in speaking activities thus resulting in a slower development of their communicative competence. These professionals feel that the learners' level of anxiety is often to blame for such reluctance to speak in the L2.

Computer conferencing technologies such as email, chat rooms, or bulletin boards have the potential of providing a low-anxiety environment for spoken interaction, since their features eliminate the learner's exposure to the physical presence of others who might negatively evaluate performance. These technologies are increasingly being used in L2 courses and have expanded the communicative reach of the classroom by breaking the time and space barriers typical of that environment. However, in spite of their conversational nature, these mostly textbased technologies lack the voice element that is essential to the improvement of oral skills.

Technological advances in recent years have made it possible to add the dimension of voice to these formerly text-only technologies. These new tools have the potential of breaking yet another barrier of the classroom environment: the high level of anxiety that students experience when participating in oral interaction in the L2. As these new communication environments emerge, there is a need in our profession for more empirical research that improves our understanding of the benefits that they provide to language learners, particularly as it pertains to affective variables such as anxiety.

To that end, this article presents the findings of a study that sought to investigate the influence of asynchronous computer voice conferencing on learners' anxiety when speaking in a L2. The technology selected was the Wimba voice board, a voice-conferencing tool that resembles a text-based bulletin board, except that the messages are posted using voice instead of written words. The Wimba voice board was integrated into a college-level intermediate Spanish course through the development of a series of activities that required students to take part in several electronic discussions. Data collection took place after the implementation of the Wimba activities and it was guided by the following research questions:

1. What is the learners' perception of their language anxiety when speaking in an asynchronous computer voice conferencing environment?

2. How concerned are the learners about being evaluated by others when making oral mistakes in the L2 in an asynchronous computer voice conferencing environment?

3. How empowered do the learners feel to take risks in an asynchronous computer voice conferencing environment? 


\section{LITERATURE REVIEW}

In the first review of the literature on the subject of anxiety and L2 learning, Scovel (1978) pointed to the particular distinction between facilitating and debilitating anxiety as the proper direction for L2 anxiety research. Facilitating anxiety is mild and enhances the learning process while debilitating anxiety is intense and holds learning back. Given the difficulties found by L2 educators to encourage oral interaction, it is important to point out that the anxiety addressed in the present study is that of the debilitating kind.

The second significant distinction of anxiety refers to trait anxiety, a natural disposition of an individual to be anxious and state anxiety, a transitory emotion that is experienced at a specific point in time (Spielberger \& Gaudry, 1971). In addition, research on the effects of anxiety on L2 acquisition has focused on a third kind, which has been called situation specific anxiety (Ellis, 1994; Horwitz, Horwitz \& Cope, 1986; MacIntyre \& Gardner, 1991). This anxiety reaction is aroused by welldefined situations such as speaking in public, participating in class, or speaking in a foreign language. Horwitz et al. (1986) identified language anxiety as a unique variable within the scope of situation-specific anxiety. The uniqueness of language anxiety stems from the difficulty of expressing ideas in a channel that is not completely mastered by the speaker. In order to measure language anxiety and to identify anxious students, Horwitz et al. developed the Foreign Language Classroom Anxiety Scale (FLCAS). Although a concern has been raised that the scale may be measuring student perceptions of their skills, rather than anxiety (Sparks \& Ganschow, 2007), this scale has become the most widely-used measure on language anxiety research.

This research has shown a strong relationship between language anxiety and achievement in all skills (Aida, 1994; Gardner, Tremblay, \& Masgoret, 1997; Onwuegbuzie, Bailey, \& Daley, 2000). However, in the experience of L2 educators it is oral communication that is most affected by anxiety. In effect, several studies have found a negative relationship between oral proficiency and anxiety (Ehrman and Oxford, 1995; Ellis, 1994; Phillips, 1992; Young, 1986). Furthermore, the cause of anxiety has been found to be a fear of performing in front of others who may negatively evaluate a learner's speaking skills (Aida, 1994; Bailey, 1983; Chen, Horwitz \& Schaller, 1999; Horwitz et al. (1999); Young, 1990), especially if a mistake is made (Bailey, 1983; Young, 1990), or during interaction with native speakers (Woodrow, 2006). Horwitz (2002) pointed out that a common reaction to this fear of negative evaluation is the learner's avoidance of those situations that constitute a source of anxiety. This reaction reduces the learners' proneness to risktaking and participation in oral communication (Ely 1986). In effect, Phillips (1992) observed that students with high anxiety tended to produce shorter communicative units, and use less complex structures in the L2. In the same way, Steinberg and Horwitz (1986) observed that L2 students exposed to conditions 
that fostered high language anxiety used less interpretive language, with fewer personal contributions, than those exposed to more relaxed conditions.

\section{Text-Based Computer Conferencing \& SLA}

Computer networks have enormous potential to enhance the language learning experience, since they provide new opportunities for communication (Chun \& Plass, 2000). Moreover, this communication takes place at the learner's convenience, and without any time constraints (Walther, 1996). The benefits of the use of these technologies are next organized in sections according to how they provide insight into the research questions.

\section{Learner Anxiety}

A number of studies in text-based synchronous computer conferencing have found that this environment provides a low-stress atmosphere that motivates the learners and significantly facilitates self-expression (Beauvois, 1994, 1996, 1999 ; Kivela, 1996; Kronenberg, 1995; Lee, 2004; Meunier, 1998; Skinner \& Austin, 1999; Warschauer, 1996a). During the experiments, students felt less anxious and enjoyed the experience of communicating in this environment because of the additional time to think and organize their ideas in the network as opposed to regular face-to-face discussions (Beauvois, 1996; Kivela, 1996).

Alternatively, Lee (2004) showed results that conflict with previous research. Students still felt anxious and afraid of making mistakes when talking to native speakers, but the author points to the learners' level of proficiency in the L2, their computer skills, and age differences as factors that may have influenced those results. Additionally, Kivela (1996) and Beauvois (1994) found that some students observed that they could not improve their oral skills, due to the text-based nature of the technology.

Research has also shown that poor instructional design can hinder the benefits of computer-conferencing technologies. Findings reveal that technology integration must be goal-oriented and fully integrated into the syllabus so that students do not see it as a superfluous addition to the course (Beauvois, 1999; Meunier, 1998; Skinner \& Austin, 1999; Warschauer, 1996b). Instructional design must also include training in the use of the technological tools so that they do not become an additional source of anxiety (Beauvois, 1999; Skinner \& Austin, 1999; Weasenforth, Lucas, and Meloni, 2002). 


\section{Negative Evaluation}

Although in some cases students disliked the sense of responsibility that the public and archived nature of the technologies involved (Sengupta, 2001), computer conferencing technologies have been shown to create a relaxing environment that reduces fear of negative evaluation. Students are less afraid of making errors in front of the whole class or the instructor in the electronic medium than they are in the classroom (Beauvois, 1996; Chun, 1994; Kelm, 1992; Kivela, 1996).

\section{Risk-Taking}

Computer conferencing has been shown to empower students to take risks with the L2 in several ways: 1) the number of contributions per student and the complexity of the language increase (Beauvois, 1992, 1994; Kelm, 1992; Kern, 1995; Skinner \& Austin, 1999), 2) learners express their opinions more freely (Beauvois, 1994, 1999; Kelm, 1992), and 3) negotiation of meaning is increased (Blake, 2000; Chun, 1994; Pelletieri, 2000;Toyoda, 2002; Warschauer, 1996a). The result of this increased risk-taking is an equalization of the interaction where the more introverted students, who would be silent in the classroom, are empowered to contribute their ideas in the computer conferencing environment (Beauvois, 1992, 1999; Chun, 1994, Kelm, 1992; Kronenberg, 1995; Skinner \& Austin, 1999; Warschauer, 1996a; Weasenforth et al., 2002). In addition, students take control of the conversation, as opposed to the traditional classroom where most interaction centers on the instructor (Chun, 1994;Kamhi-Stein, 2000; Kern, 1995).

\section{Voice Conferencing \& SLA}

Research on student perceptions of their communication experiences using synchronous voice conferencing technologies has yielded mixed results. The use of a phone-based system at Open University of the United Kingdom allowed students to concentrate more on the message and less on grammatical errors (Stevens \& Hewer, 1998). On the other hand, students remained reserved and insecure about communicating in an electronic learning environment later developed by the same university. The following year, similar results were found with the use of synchronous communication software at Open University. Nonetheless, tutors and students felt that oral skills had improved and that students were more in control of the discussions (Hampel, 2003; Hampel \& Hauk, 2004; Kötter, Shield \& Stevens, 1999).

The use of asynchronous voice computer conferencing has yielded more promising results. Two studies have looked at the use of the Wimba voice board in foreign language teaching. Cho and Carey (2001) observed that the Wimba 
technology reduced anxiety in students of Korean. The benefit of the use of this technology increased accuracy and fluency in listening and speaking. Students had more time to listen and reply to questions, they could repeat the recordings as many times as they needed, and they did not feel the pressure of having an interviewer in front of them. McIntosh Braul, and Chao (2003) found that the Wimba voice board was a non-threatening environment that improved their speaking and listening skills.

\section{Technology Integration}

The present project consisted on the development of a series of Wimba activities (see Appendix A) and their implementation in two college-level Intermediate Spanish sections. Students were asked to answer a question posted by the instructor on the voice board. After listening to the opinions of their classmates, they replied to somebody's posting. All contributions to the voice board were posted outside of class and the language laboratory was made available for this purpose. However, students who owned the necessary equipment and wished to post their messages from home were allowed to do so. After the implementation of the Wimba activities, data was collected to compare the anxiety experienced by the students in the electronic environment to the anxiety experienced during classroom discussions.

\section{Methodology}

A mixed-methods design involving both quantitative and qualitative data was chosen based on Daly (1991) and McCroskey (1984) who suggest that self reported measures such as interviews and questionnaires are the most valid indicators of anxiety. These authors also indicate that other instruments are to be used only in combination with self-reported measures.

The participants of the present study were 48 students enrolled in two sections of a college-level Intermediate Spanish course. Both classes participated in discussions that took place in the classroom and Wimba environments. All participants were undergraduate students whose first language was English and their ages ranged from 19 to 35 years old. 13 (37.1\%) of them were male, and 22 (62.9\%) were female. All students majored in areas related to the arts, sciences, business, and education, and none majored in Spanish. The majority (91.4\%) of the students took Spanish as a requirement for graduation and five participants took Spanish because of personal interest. Regarding their motivation, most participants (57.1\%) described it as medium, $31 \%$ described it as high, and $11.4 \%$ described it as low.

For the qualitative component of the investigation, a total of four students, two from each section, were selected to participate in the interviews. Only participants who had contributed to both the face to face and Wimba discussions were chosen. In 
addition, the participants were selected based on either a personal communication with the researcher expressing high levels of anxiety, or their apparent reluctance to participate in class discussions.

After the implementation of the Wimba activities, a demographic survey was administered to students, followed by the Computer Anxiety Index (CAIN) developed by Simonson, Maurer, Montag-Torardi, and Whitaker (1987). These two instruments were aimed at thoroughly describing the participants and at determining if computer anxiety was a confounding variable that could affect the results of the study. In order to determine students' perceptions of their anxiety in the classroom, they also completed the Foreign Language Classroom Anxiety Scale (FLCAS), developed by Horwitz et al. There were a number of items on the FLCAS that were not relevant to the present investigation and were therefore removed. More specifically, items related to test anxiety were eliminated, since the study was concerned exclusively with the anxiety produced by speaking in the $\mathrm{L} 2$. In the same way, items related to fear of not being prepared for class, or anxiety about failing the course were also eliminated. As a result of this elimination process, 18 of the 33 items of the original FLCAS were used in this study. 73\% of the students (35 of the 48 students enrolled) completed this series of questionnaires. Subsequently, and following a brief training session, the Wimba activities were assigned for a total of six weeks as a supplement of the course. During that time, several classroom discussions were recorded at random so that the recorder did not become an additional source of anxiety.

Following the implementation of the Wimba activities, students completed the Wimba Anxiety Scale (see Appendix B). This scale is a modified version of the FLCAS that was developed to evaluate anxiety on the Wimba environment. Since the Wimba Anxiety Scale was intended to address two different research questions, it was divided into two subscales. Scores from the Wimba Subscale 1 were analyzed to answer research question 1 , students' perceptions of their anxiety, and scores from the Wimba Subscale 2 were analyzed to answer research question 2, fear of negative evaluation. Content validity of the subscales was established in order to ensure that the individual items as well as the instructions to participants were clear and the items were representative of the research questions. A panel of three experts from the fields of Second Language Acquisition, Instructional Technology, and Computer-Assisted Language Learning determined the content validity of the Wimba Anxiety Scale. Content validity was established with an interrater reliability of 1.0.

With the purpose of providing insights into research question 3 a rubric was developed that assessed the amount of risk-taking on the linguistic output produced on the Wimba and classroom environments. Based on the suggestions of Ortega (1997), the rubric assessed multiple features of the linguistic output, such as the number of words per contribution, the complexity of sentences, and the number of errors. In addition, it measured participation patters such as the number of student versus teaching contributions, the amount of English used, the number of questions 
made by students, and examples of negotiations of meaning. The linguistic output analyzed was taken from transcripts of student contributions posted on Wimba on a selected discussion topic as well as from a tape-recorded classroom discussion about the same topic.

For the qualitative component of the investigation a series of interviews with selected participants were conducted after completion of the Wimba activities. The interviews provided in-depth data about the students' level of anxiety in both environments. Interview questions addressed student perceptions of their anxiety in the Wimba environment, their concern about negative evaluation by others, and their willingness to take risks.

\section{RESUlTS \& DiscuSSION: QUANTITATIVE}

The CAIN measured the participants' level of computer anxiety. An independent samples $t$-test was conducted in order to determine if there was a significant difference between the two sections of the intermediate Spanish course that participated in the study. Since no statistically significant difference was found, the scores were combined and treated as a single group. The CAIN index was computed by totaling the scores of all items. With the purpose of determining if the anxiety level of this particular group of students was high in comparison to similar students, the mean computer anxiety index of the participants was contrasted with the mean index typical of college students reported by Simonson et al. (1987) The mean and standard deviation of the participants of the present study, in contrast with those reported by Simonson et al., are presented in Table 1.

Table 1: Descriptive Statistics of the CAIN for the Two Studies

\begin{tabular}{lcc}
\hline & Present Study & Simonson et al. (1987) \\
\hline Number & 35 & 545 \\
\hline Mean & 53.1 & 62.33 \\
\hline Standard Deviation & 13.3 & 17.76 \\
\hline Note: Possible range 26-156. A higher mean indicates a higher level of anxiety.
\end{tabular}

The CAIN showed that the level of computer anxiety of the participants of this study was lower than that reported by Simonson et al. for college students. Consequently, computer anxiety was ruled out as a significant confounding variable in the present investigation. 
Poza

\section{RQ1: Participants Perceptions of their Anxiety}

Research Question 1: What is the Learners' Perception of their Language Anxiety When Speaking in an Asynchronous Computer Voice Conferencing Environment?

In order to answer this question, the language anxiety experienced by the participants when speaking in the classroom was compared to that of theWimba environment though the administration of the FLCAS and Subscale 1 of the Wimba Anxiety Scale.

The participants' level of language anxiety in the classroom was measured by the FLCAS. An independent samples t-test was conducted in order to determine if there was a significant difference between the two sections that participated in the study. Since no statistically significant difference was found, the scores were combined and treated as a single group. The possible range of scores for the FLCAS was 18-90, with higher numbers indicating a higher level of anxiety. The mean score for the FLCAS was 53.3 (SD = 4.329), and the range was 20-89. Students experiencing moderately high and low anxiety were identified by their scoring one standard deviation above and below the mean respectively. Students experiencing very high and low anxiety were identified by their scoring two standard deviations above and below the mean respectively. Figure 1 illustrates the distribution of the participants by levels of language anxiety.

Figure 1: Distribution of Anxiety Levels

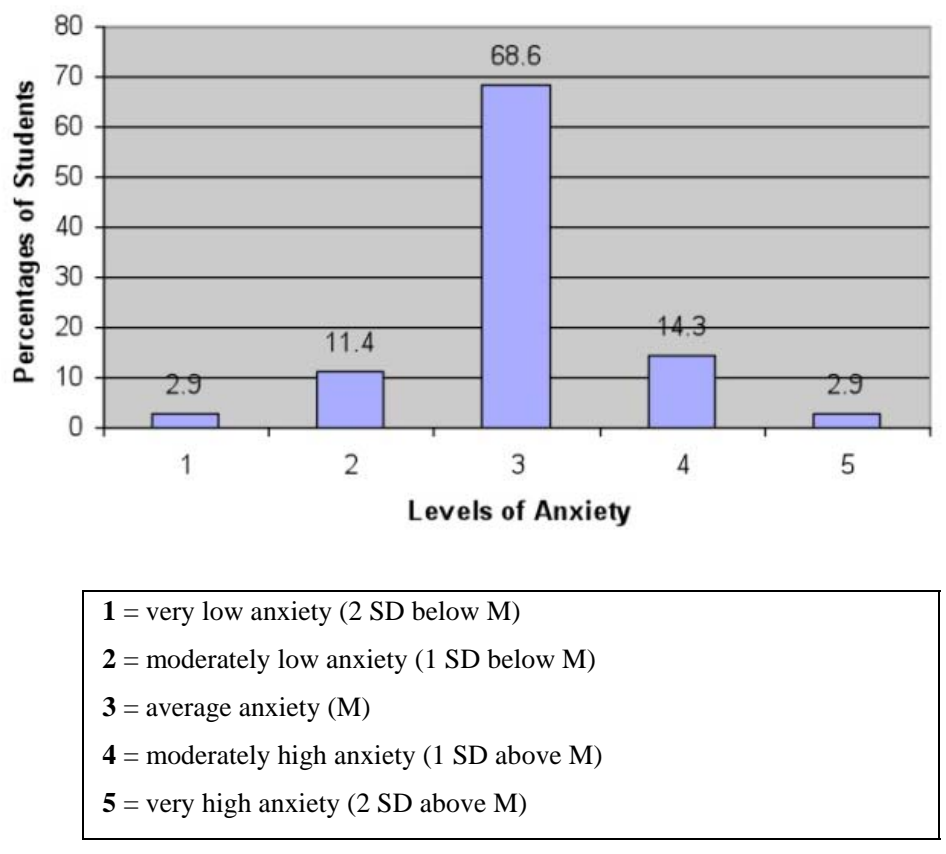

Vol. 41 (1) 2011 
The data presented in Figure 1 above show that the majority of participants experienced average anxiety in the classroom, with a greater percentage of high than low anxiety. Item analysis revealed that the majority of the students showed high levels of anxiety on items related to speaking in the classroom (26\% strongly agreed, and 51\% agreed), making mistakes (8.6\% strongly agreed, and 51.4\% agreed), speaking to native speakers of the language (17.1\% strongly agreed, and $42.9 \%$ agreed), and thinking that the other students are better at languages (8.6\% strongly agreed, and $40 \%$ agreed). Additionally, students were more anxious in their language class than in other classes (8.6\% strongly agreed, and $42.9 \%$ agreed).

A total of 29 students ( $60 \%$ of the 48 enrolled) completed the Wimba Anxiety Scale. An independent samples $t$-test was conducted in order to determine if there was a significant difference between the means of the two sections. Since a statistically significant difference was not found, the scores were combined and treated as a single group. The possible range of scores for Subscale 1 was 8-40, with higher values indicating a higher level of anxiety. The mean score for this subscale was 19.07 (SD = 6.761), and the range was 8-36. Additionally, as with the FLCAS, participants were grouped by levels of anxiety according to their scores in Subscale 1. Figure 2 illustrates the distribution of the participants by levels of language anxiety.

Figure 2: Distribution of Language Anxiety Levels for Subscale 1

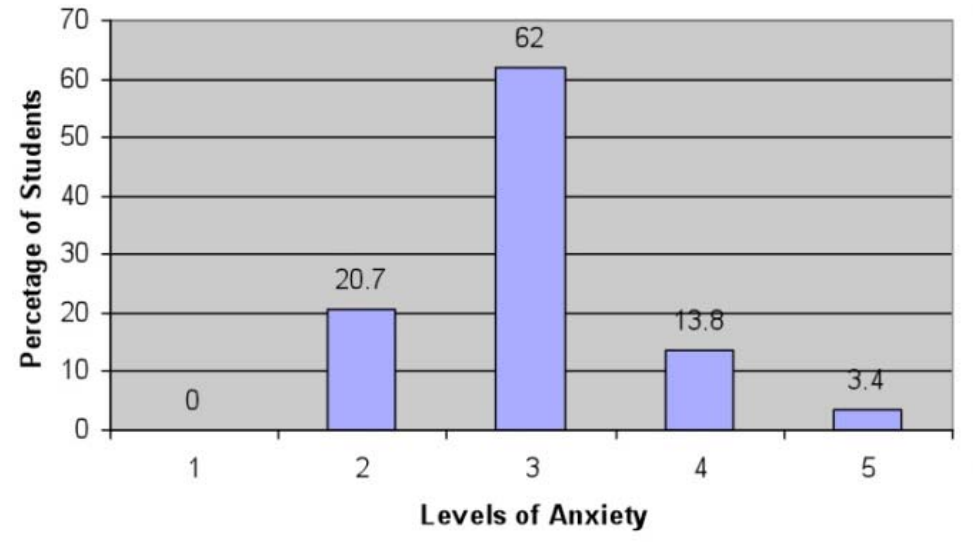

Similarly to the classroom, the data presented in Figure 2 show that the majority of the participants experienced an average level of anxiety onWimba. However, as opposed to the classroom, there was a greater percentage of low versus high anxiety. Item analysis revealed that the majority of the students experienced a high level of anxiety about talking to native speakers in the computer environment that was similar to that of the classroom (Classroom: $17.1 \%$ strongly agreed and $42.9 \%$ agreed. Wimba: $17.2 \%$ strongly agreed and $37.9 \%$ agreed). However, students 
reported lower levels of anxiety in items related to speaking Spanish on Wimba than in the classroom (Classroom: 26\% strongly agreed, and 51\% agreed.Wimba: 10.3\% strongly agreed, and $17.2 \%$ agreed).

\section{RQ 2: Anxiety towards Negative Evaluation}

Research Question 2: How Concerned Are the Learners about Being Evaluated by Others When Making Oral Mistakes in the Foreign Language in an Asynchronous Computer Voice Conferencing Environment?

The participants' concern for negative evaluation was measured by Subscale 2 of the Wimba Anxiety Scale. The possible range of scores was 9-45, with higher values indicating a higher level of anxiety. The mean score for this subscale was $23.07(S D=6.204)$, and the range was $14-36$. The participants were grouped by levels of anxiety, according to these values and their scores in Subscale 2. Figure 3 illustrates the distribution of the participants by levels of language anxiety.

Figure 3: Distribution of Language Anxiety Levels for Subscale 2

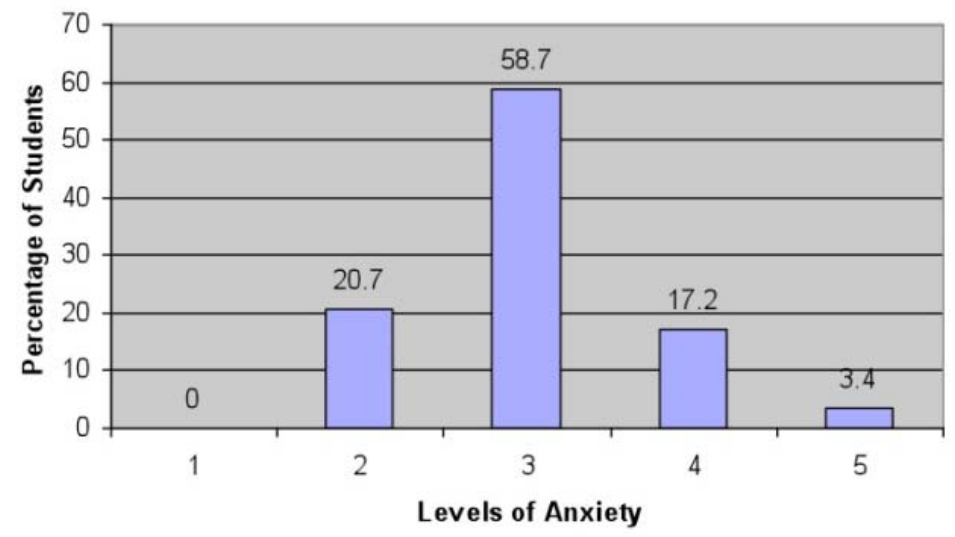

Figure 3 shows that, as in the classroom environment, most students experienced an average level of anxiety on Wimba, with virtually equal percentages of high and low anxiety. The results of the item analysis revealed that the majority of the students were anxious about making mistakes in the asynchronous computer voice conferencing environment in similar percentages as the classroom (Classroom: 8.6\% strongly agreed, and $51.4 \%$ agreed. Wimba: $13.8 \%$ strongly agreed, and $41.4 \%$ agreed). However, the data indicate that the students were less anxious about the possibility of the instructor correcting their mistakes (Classroom: 5.7\% strongly agreed, and $11.4 \%$ agreed. Wimba: $0 \%$ strongly agreed, $0 \%$ agreed). Students also 
reported to experience less anxiety about thinking that the others were better at the L2 (Classroom: $14.3 \%$ strongly agreed and $40 \%$ agreed. Wimba: $0 \%$ strongly agreed and $34.5 \%$ agreed).

\section{RQ 3: Risk-Taking}

Research Question 3: How Empowered Do the Learners Feel to Take Risks in an Asynchronous Computer Voice Conferencing Environment?

The students' contributions to classroom and computer discussions were analyzed by the use of an evaluation rubric. An independent samples $t$-test was conducted to determine if there was a significant difference between both sections. Since no significant difference was found, both sections were treated as a single group. Independent samples $t$-tests were also conducted to determine if there were significant differences between the Wimba and classroom environments in the number of words, sentences, simple and complex sentences, and errors in student contributions. The results for both environments are presented in Tables 2 and 3.

Table 2: Evaluation of Classroom and Wimba Discussions

\begin{tabular}{lcc}
\hline & Classroom & Wimba \\
\hline Student contributions & 176 & 66 \\
\hline Instructor contributions & 249 & 2 \\
\hline Number of contributions in English & 23 & 0 \\
\hline Questions in the discussion & 7 & 0 \\
\hline Requests for clarification by students & 2 & 0 \\
\hline Occasions in which feedback was given to other students & 14 & 26 \\
\hline Elaborations and expansions of previous contributions & 27 & 5 \\
\hline
\end{tabular}

The findings of the evaluation of the negotiation of meaning in both environments show a very small number of requests for clarification by students. In contrast, more student feedback was given to other students during the discussions on the voice board than in the classroom. This was due to the design of the Wimba activities, which required the students to react to the opinions of their classmates. In addition, the data show that there were more elaborations and expansions of previous contributions by students in the classroom than in the computer environment. However, the elaborations and expansions that occurred in class were requested by the instructor, as opposed to those on the voice board, which were spontaneous. Therefore we can conclude that the Wimba voice board empowered learners to elaborate on previous contributions thus increasing negotiation of meaning. 
Table 3: Evaluation of Student Contributions

\begin{tabular}{lll}
\hline \multicolumn{1}{c}{ Student Contributions } & Environment & Mean \\
\hline \multirow{2}{*}{ Words per contribution } & Classroom & 3.9 \\
\cline { 2 - 3 } Sentences per contribution & Wimba & 29 \\
\hline \multirow{2}{*}{ Simple sentences per contribution } & Classroom & .39 \\
\cline { 2 - 3 } & Wimba & 2.38 \\
\hline \multirow{2}{*}{ Complex sentences per contribution } & Classroom & .09 \\
\cline { 2 - 3 } & Wimba & 1.24 \\
\cline { 2 - 3 } Errors per contribution & Classroom & .3 \\
\hline
\end{tabular}

Table 3 shows a significantly higher number of both words and sentences on the Wimba environment. Additionally, as shown in Table 2, the students tended to turn to English in classroom conversations, a tendency that did not occur in the computer environment. Furthermore, the $t$-tests used to compare both environments indicated that the mean of the Wimba environment was in all cases significantly higher than in the classroom. Specifically, an independent samples $t$-test on words showed significant differences between both environments: $t=-13.057(\mathrm{p}<.01)$ and an independent samples $t$-test on sentences showed significant differences between both environments: $t=-12.050(\mathrm{p}<.01)$. It becomes clear that there was a greater quantity of output in the asynchronous computer environment than in the classroom.

Concerning the complexity of the output, an independent samples $t$-test on simple sentences showed significant differences between both environments: $t=$ $10.651(\mathrm{p}<.01)$. An independent samples $t$-test on complex sentences also showed significant differences between both environments: $t=-5.585(\mathrm{p}<.01)$. Students produced a significantly greater number of complex sentences in the asynchronous environment. These findings indicate a greater complexity of output in the Wimba environment.

In terms of the accuracy of the output, the data indicate that the students made more errors on Wimba than in classroom discussions. An independent samples $t$-test on errors showed significant differences between the environments: $t=-5.387(\mathrm{p}<$ .01 ). Reduced accuracy is an obvious consequence of the greater amount and complexity of language produced on the Wimba environment. Students were taking risks and experimenting with the L2 in the computer environment, whereas in the 
classroom the smaller amount and complexity of output allowed for a lesser number of grammatical mistakes.

\section{Correlation Analyses}

A total of four Pearson product moment bivariate correlational analyses were conducted in order to investigate the relationship between each subscale of the Wimba Anxiety Scale and the CAIN on the one hand, and the shortened FLCAS on the other. As shown in Table 4, the results indicate that there was not a statistically significant relationship between computer anxiety, measured by the CAIN, and any of the Wimba anxiety subscales, further supporting the conclusion that computer anxiety was not a confounding variable in the present investigation. Similarly, there was not a statistically significant relationship between classroom language anxiety, measured by the FLCAS, and anxiety from fear of negative evaluation, measured by Subscale 2 of the Wimba Anxiety Scale. In contrast, classroom language anxiety was found to be positively correlated with anxiety about speaking the language on the voice board, measured by the Wimba Subscale 1. According to this, anxiety on Wimba increased as classroom anxiety increased. This positive correlation, together with the similarity in the distributions of anxiety levels between the FLCAS and both subscales of the Wimba Anxiety Scale indicate that, as far as quantitative data is concerned, the overall level of language anxiety felt by students on the voice board was very similar to that felt in the classroom.

Table 4: Correlation of CAIN \& FLCAS with Wimba Anxiety Subscales

\begin{tabular}{lcc}
\hline & Wimba Anxiety Subscale 1 & Wimba Anxiety Subscale 2 \\
\hline CAN & .223 & .278 \\
\hline FLCAS & $.626^{* *}$ & .376 \\
\hline Note. ${ }^{* *}$ Correlation is significant at the 0.01 level (2-tailed)
\end{tabular}

\section{RESUlts \& Discussion: QUALITATIVE}

Qualitative data from individual participants was also collected in order to help interpret the quantitative findings. Participants' names were changed to other names of their choice, in order to protect their anonymity.

Anita was 19 years old and was taking Spanish as a requirement for her major. Her CAIN index indicated a low level of computer anxiety. Her language anxiety, as indicated by her score in the FLCAS, was moderately high, although, prior to the interview, she reported to the researcher that the reason why she did not volunteer in 
class was a very high level of anxiety. Her score on the Wimba Anxiety Scale was moderately low.

Robert was 20 years old and was taking Spanish as a requirement for his major. His CAIN index indicated a high level of computer anxiety. His language anxiety was average. He was selected because of his apparent reluctance to volunteer during oral discussions in class. Finally, his anxiety on Wimba was moderately high.

Marly was 23 years old and was taking Spanish as a requirement for her major. Her CAIN index indicated a low level of computer anxiety. Her language anxiety, as indicated by her score in the FLCAS, was average. However, prior to the study, she had verbally reported to the researcher being nervous during oral discussions in class. Finally, her level of anxiety on Wimba was also average.

Jane was 23 years old and was taking Spanish as a requirement for her major. Her CAIN index indicated a low level of computer anxiety, and her score in the FLCAS indicated that her language anxiety was average. In spite of this data, she was selected because of her apparent reluctance to volunteer during oral discussions in class. Finally, her level of anxiety on Wimba was also average.

\section{RQ1: Participants' Perceptions of Their Anxiety}

All four participants described their level of anxiety when speaking on Wimba as low. Three of the four participants shared that their level of anxiety was lower than that of the classroom. As Anita described:

In... On a scale of one to ten, in class, it's about a nine, eight or nine, but on Wimba, it's four at the most.

The main reason for this reduction in the level of anxiety as reported by three of the four participants was freedom from the time pressure of the classroom. More specifically, the asynchronous nature of the voice board slowed the pace of interaction and helped them feel more comfortable. As Marly said:

Yeah, that's... that's different because it's in front of the whole class and then you, you're you know, you don't have time for me, sitting there, like, taking five, six minutes to answer a question. Wimba... you can take as long as you need... to design your sentence that you're gonna say, and listen to as many people as you want, over and over again. I mean, you have all the time in the world, but when you are in a class setting, you've got fifty minutes with all those other students, and then you're called on, you really don't know what to say.

An additional theme that emerged during data analysis was the critical importance of the facility where students accessed Wimba. When asked to identify 
the worst aspect of the Wimba assignment, three of the four participants mentioned going to the language laboratory. In effect, interview data revealed that the layout and condition of the facility hindered Wimba's anxiety-reducing potential by creating new sources of stress for those students who chose to post their contributions from that facility. In their description of the language laboratory participants consistently referred to four major issues: 1 ) the presence of others, 2) the proximity of the computers, 3) restrictive laboratory hours, and 4) technical issues.

As shown by their responses, students felt that the presence of others around the computer where the Wimba environment was being used increased their level of anxiety. This was found to be true for the language laboratory as well as the students’ rooms. As Anita said:

I've been in my room and I've had to get everyone out because they don't speak Spanish and I feel kind of weird speaking Spanish in front of them into a microphone, huh... mainly because they don't really know what I'm saying and I feel kind of bad doing that.

Jane mentioned a similar concern as she described her experience using Wimba in a crowded laboratory:

I remember trying to talk low like, I had the microphone right to my mouth and I was like talking like this because I didn't want everyone to hear it in case I messed up and I had to re... redo my reply... do that again. Ahh I didn't want people to... hear my Spanish, honestly, so I was kind of leaning forward to the computer and doing the... speaking into the microphone really low.

These comments show that fear of negative evaluation, one of the main causes of language anxiety, was not totally eliminated in the Wimba environment. The close proximity of the computers in the language laboratory further aggravated the issue. As Jane said:

[...] Just everybody being so close, like it was kind of, that's something that made me nervous, was the people all close beside me. [...] Like everything was so close together, and there should have been more space, I think, to make it comfortable. [...] Maybe there could be a section for Wimba, like instead of having all the computers together. [...]. Maybe they could designate some computers for that over there that are more... spread out or away from just everybody else who are just checking their email and doing other things, like papers and homework and stuff.

This comment made by Jane describes a less than ideal laboratory setup, but also points to a possible solution to the issue. Having a separate section at the language laboratory, free from the presence of others and with enough space between the computers could unleash the true anxiety-reducing potential of the Wimba voice board. 
Poza

Additionally, students complained about laboratory hours being too restrictive. As Robert said:

The worst thing is having to go to the computer lab. [...] I don't think it would be so bad if the lab was open all the time.

Jane agreed:

The worst thing would be the lab hours weren't... huh... that great. It was hard to do that in between, like, classes and things like that.

Based on these comments, we can conclude that the lack of flexibility in laboratory hours increased students' frustration about completing the Wimba activities, thus hindering the anxiety-reducing potential of the technology. More flexible laboratory hours would have reduced the students' affective filter by fostering a more positive attitude towards completing the assigned Wimba activities.

Finally, three of the four students interviewed complained about technical difficulties experienced at the language laboratory, especially those related to the poor quality of microphones, which made students contributions sound fuzzy and difficult to understand. As Jane and Anita described:

Some of the headsets are kind of like... fuzzy, they make a static noise.

Occasionally the microphone would be messed-up and... I think that was the people who went to the lab.

These comments reveal the critical importance of ensuring that technical difficulties are either eliminated or reduced to a minimum. Clearly, technical problems often increase frustration and anxiety thus hindering the teaching potential of instructional technology.

Based on interview data, we can conclude that in the present investigation the properties of the Wimba environment that are conducive to the reduction of anxiety were counterbalanced by the characteristics of the facility where voice board was accessed. The proximity of the computers, coupled with the lack of an isolated area where Wimba could be accessed free from the presence of unwanted listeners increased language anxiety in this group of students.

In addition, restrictive laboratory hours and frequent technical difficulties caused students to have a negative attitude towards completing the activities which in turn may have increased their anxiety. This finding of the qualitative data explains the inconclusive results of the quantitative analysis in terms of overall level of anxiety that students experienced on Wimba compared to that of the classroom environment. 
The Effects of Asynchronous...

\section{RQ2: Anxiety towards Negative Evaluation}

Three of the four students interviewed agreed that the absence of the instructor and peers when using Wimba helped to reduce anxiety. As Marly shared:

Yeah, I... I enjoyed being able to do that on your own time, and not worrying about others, what others are thinking, or you know, if you sound not that great for a Spanish four student or, yeah I, I like that you can go... and be by yourself or be with friends and you can feel much more comfortable.

In addition, the fact that both their instructor and their classmates would eventually listen to their contributions did not make a difference in their anxiety, as expressed by Jane:

I didn't... I didn't even think about it, honestly, 'cause I was just like... it just... it didn't bother me and I wasn't worried because ahh there ... I don't know, I don't really have a reason. I just, it just didn't bother me as much as it would if I was in class and having to respond because I wrote it out and then I read it, I read it and tried to pronounce it the best I could and then... you know, that's better than I could do in class at times.

Freedom from the time limits of the classroom and the opportunity to write their answers contributed to a reduction of the fear of negative evaluation experienced in the asynchronous environment. By having more time to prepare their answers, students gained a sense of security about the quality and accuracy of their output. This was also made possible by the opportunity to edit their contributions as many times as they needed. As Jane said:

When I made mistakes, I started laughing and just started it over, because ahh because I knew I could start over and, you know, make up another reply, so I just ahh I just kind of laughed and started. It didn't really bother me because I knew I could correct it, fix it, and start again.

In effect, none of the students interviewed expressed a concern about making mistakes on Wimba. As Robert said:

If I made a mistake, unless it was something serious, like the sentence didn't make sense, I generally just left it out there.

The possibility that the instructor and peers would eventually listen to their contributions, and to their mistakes, did not make a difference in the students' anxiety about negative evaluation. However, as mentioned earlier, some students did feel anxious about the presence of people unrelated to their Spanish class at the language laboratory. Therefore, negative evaluation was significantly reduced on the Wimba voice board but not completely eliminated. 


\section{RQ 3: Risk-Taking}

In spite of the barriers posed by the laboratory facility, all four participants reported to have taken more risks with the foreign language on Wimba than in the classroom. In this case, interview data corroborated the findings of the evaluation rubric, which showed increased quantity and complexity of output on the voice board. As Robert shared:

I would be more likely to say something that I wasn't sure about on Wimba, as opposed to the classroom, probably. [...] I would be more likely to say something... difficult or... that I really wasn't sure if it was right... just like on a homework assignment, because... you are not in front of the class.

Two of the students referred to the grammatical complexity of their contributions in the asynchronous environment. As Anita said:

Well... the positive part is that you could think about what you're saying beforehand so that you can develop your larger sentence... more complex sentences and such, and you can get your message across better, as opposed to only using simple sentences, like you usually use in class when you are called on and you can't think of all the other stuff.

Undoubtedly the asynchronous nature of the electronic environment allowed them to gather their thoughts in advance, which resulted in a greater complexity of their oral output. In this way, the Wimba voice board empowered students to take risks in the foreign language by slowing the pace of the interaction.

\section{CONCLUSION}

Taken together, the quantitative and qualitative data suggest a number of clear conclusions for this study.

\section{RQ 1: Participants' Perceptions of their Anxiety}

Analysis of the quantitative data revealed that, although anxiety about some items of the FLCAS decreased on Wimba, the distributions of anxiety were similar in the classroom and Wimba environments. In addition, correlational analyses indicated that the overall anxiety experienced on Wimba increased as classroom anxiety increased. On the contrary, the qualitative data indicated that students experienced reduced anxiety on Wimba, attributable to both the elimination of the time pressure of the classroom and the opportunity to edit their contributions prior to posting them to the voice board. The qualitative analysis also revealed that the opportunity to edit their contributions gave the students greater confidence in the quality of their output, 
which also resulted in a lower level of anxiety. Item analysis of the two subscales of the Wimba Anxiety Scale supported this claim, since students reported to have experienced less overall anxiety about speaking on Wimba.

The qualitative data served to explain these contradictory findings. Interviews revealed that, although Wimba involves features that promote a reduction of anxiety, the participants of this study may not have fully benefitted from them. The conditions of the facility where they accessed the technology, in particular the language laboratory, exposed them to unexpected sources of anxiety such as the presence of others, the proximity of the computers, restrictive hours, and the eventuality of technical difficulties.

In effect, the interviews revealed a general negative attitude towards going to the language laboratory, which may have increased debilitating anxiety. In light of this, we can conclude that the asynchronous environment will be conducive for the reduction of anxiety only if the conditions of the location where students access the technology are controlled. Technical difficulties must be reduced to a minimum, laboratory hours must be flexible, and there should be a quiet isolated location within the facility reserved to accessing the Wimba environment. In view of the considerable effect that the language laboratory setup has on anxiety, directors need to take a second look at their facilities and ensure they are in optimal condition so that this technology truly enhances the development of oral skills.

\section{RQ 2: Fear of Negative Evaluation}

Item analysis of subscale 2 of the Wimba Anxiety Scale revealed that on Wimba, students were less anxious about thinking that their classmates were better at the L2 than in the classroom. Additionally, interview data showed decreased fear of negative evaluation on Wimba. This reduced fear of negative evaluation is attributable to the absence of the instructor and peers in this environment. Moreover, the fact that their instructor and peers would eventually listen to their contributions did not constitute an additional source of anxiety on the Wimba environment.

Finally, interviews indicated that, because students were free from the time constraints of the classroom and because they had the opportunity of editing their answers, there was a reduction of the fear of negative evaluation. However, the distributions of anxiety about fear of negative evaluation were similar in both environments. Interview data explained this fact by revealing that the presence of unwanted listeners in the language laboratory and the close proximity of the computers caused some of that fear to remain. 


\section{RQ 3: Risk-Taking}

The potential of the Wimba technology to reduce language anxiety was demonstrated by the amount of student risk-taking in that environment. The data shows that students were empowered to take more risks in the computer environment, both in the quantity and complexity of their contributions. Students attributed this increased risk-taking to two sources: 1) more time was allowed to prepare their contributions to the voice board, and 2) the pressure of being in front of the class was eliminated. This is consistent with the results reported by Beauvois (1992), Chun (1994), Kamhi-Stein (2000), and Kern (1995) who found that the quantity and quality of the output increased in the computer medium.

As a whole, the findings of the present study support the claims of previous research on text-based computer-mediated-communication. Additionally, the results are consistent with previous research on the use of the Wimba voice board for language classes (Cho and Carey, 2001;McIntosh, Braul and Chao). This is relevant for the foreign language teaching profession since the scarcity of studies about voice-based computer conferencing technologies made it impossible to determine if the anxiety-reducing benefits of text-based computer mediated communication could be attributed to voice-based environments. The present investigation represents one step forward towards reaching this goal and provides foreign language instructors with a clearer picture of the benefits and of these environments into their classes.

\section{Implications}

From a practitioner's standpoint, a number of implications stem from the findings of this research:

1. Voice computer-conferencing technologies should be used in foreign language classes.

2. To reduce language anxiety, the facility where the students access the technology must be controlled. Access to the technology should be optimized so that there are not any time constraints, and students are not exposed to the presence of others who may hear their contributions to the voice board.

3. Every effort should be made to minimize technical difficulties.

4. More research is needed to investigate the integration of asynchronous computer voice conferencing technologies, such as Wimba, in foreign language courses.

5. Further attention should be given by researchers to the impact of the place where students access the technology on affective variables such as language anxiety. 
The Effects of Asynchronous...

\section{REFERENCES}

Aida, Y. (1994). "Examination of Horwitz, Horwitz, and Cope's construct of foreign language anxiety: The case of students of Japanese.” The Modern Language Journal, 78, 155-168.

Bailey, K. M. (1983). “Competitiveness and anxiety in adult second language learning: Looking at and through the diary studies.” In H. W. Seliger \& M. $\mathrm{H}$. Long (Eds.), Classroom oriented research in second language acquisition (pp. 67-102). Rowley, MA: Newbury House Publishers Inc.

Beauvois, M. H. (1992). "Computer-assisted classroom discussion in the foreign language classroom: Conversation in slow motion.” Foreign Language Annals, 25, 455-463.

Beauvois, M. H. (1994). "E-talk: Attitudes and motivation in computer-assisted classroom discussion.” Computers and the Humanities, 28, 177-190.

Beauvois, M. H. (1996). "Personality types and megabytes: Student attitudes toward computer-mediated communication (CMC) in the language classroom.” CALICO Journal, 13, 26-45.

Beauvois, M. H. (1999). Computer-mediated communication: Reducing anxiety and building community. In D. J. Young (Ed.), Affect in Foreign Language and Second Language Learning: A Practical Guide to Creating a Low Anxiety Classroom Atmosphere (pp. 144-165). Boston: McGraw Hill.

Blake, R. (2000). "Computer-mediated communication: A window in L2 Spanish Interlanguage.” Language Learning and Technology, 4, 120-136. Retrieved March 5, 2004 from .

Chen, Y., Horwitz, E. K., \& Schaller, D. L. (1999). “Language anxiety: Differenciating writing and speaking components.” Language Learning, 49, 417-447.

Cho, S. P., \& Carey, S. (2001). "Increasing Korean oral fluency using an electronic bulletin board and Wimba-based voiced chat.” The Korean Language in America, 6, 115-128.

Chun, D. M. (1994). "Using computer networking to facilitate the acquisition of interactive competence.” System, 22, 17-31. 
Chun, D. M. \& Plass, J. L. (2000). "Networked multimedia environments for second language acquisition.” In M. Warschauer \& Kern, R.G.(Eds.), Network-Based Language Teaching: Concepts and Practice (pp. 151-170). Cambridge: Cambridge University Press.

Daly, J. (1991). "Understanding communication apprehension: An introduction for language educators.” In E. K. Horwitz \& D. J. Young (Eds.),Language Anxiety: From Theory and Research to Classroom Implications. Englewood Cliffs, NJ: Prentice Hall.

Ehrman, M. E., \& Oxford, R. L. (1995). "Cognition plus: Correlates of language learning success.” The Modern Language Journal, 79, 67-89.

Ellis, R. (1994). The Study of Second Language Acquisition. New York: Oxford University Press.

Ely, C. M. (1986). "Language learning motivation: A descriptive and causal analysis.” The Modern Language Journal, 70, 28-35.

Gardner, R. C., Tremblay, P. F., \& Masgoret, A. M. (1997). “Towards a full model of second language learning: An empirical investigation.” The Modern Language Journal, 81, 344-362.

Hampel, R. (2003). "Theoretical perspectives and new practices in audio-graphic conferencing for language learning.” ReCALL, 15, 21-36.

Hampel, R. \& Hauk, M. (2004). "Towards an effective use of audio conferencing in distance language courses.” Language Learning and Technology, 8, 66-82. Retrieved February 27, 2004, from .

Horwitz, E., Horwitz, M. B., \& Cope, J. (1986). "Foreign language classroom anxiety.” The Modern Language Journal, 70, 125-132.

Horwitz, E. (1986). "Preliminary evidence for the reliability and validity of a foreign language anxiety scale.” TESOL Quarterly, 20, 559-562.

Horwitz, M. B. (2002). Communication Apprehension. Albany, NY: Delmar Singular.

Kahmi-Stein, L. D. (2000). "Looking to the future of TESOL teacher education: Web-based bulletin board discussions in a methods course.”TESOL Quarterly, 34, 423-455. 
The Effects of Asynchronous...

Kelm, O. R. (1992). "The use of synchronous computer networks in second language instruction: A preliminary report.” Foreign Language Annals, 25, 441-454.

Kern, R. G. (1995). "Restructuring classroom interaction with networked computers: Effects on quantity and characteristics of language production.” The Modern Language Journal, 79, 457-476.

Kivela, R. J. (1996). "Writing on networked computers: Effects on ESL writer attitudes and apprehension.” Asian Journal of English Language Teaching, 6, 85-92.

Kötter, M., Shield, L., \& Stevens, A. (1999). "Real-time audio and email for fluency: Promoting distance language learners’ aural and oral skills via the Internet.” ReCALL, 11, 55-60. Retrieved February 17, 2004, from .

Kronenberg, N. (1995). "Developing communicative and thinking skills via electronic mail.” TESOL Journal, 4, 24-27.

Lee, L. (2004). "Learners' perspectives on networked collaborative interaction with native speakers of Spanish in the U.S." Language Learning and Technology, 8, 83-100. Retrieved February 27, 2004, from .

MacIntyre, P. D., \& Gardner, R. C. (1991). "Methods and results in the study of anxiety and language learning: A review of the literature."Language Learning, 41, 85-117.

McCroskey, J. C. (1984). “The communication apprehension perspective.” In J. A. Daly \& J. C. McCroskey (Eds.), Avoiding communication (pp. 78-96). Beverly Hills, CA: Sage Publications.

McIntosh, S., Braul, B., \& Chao, T. (2003). "A case study in asynchronous voice conferencing for language instruction.” Education Media International, 40, 63-74.

Meunier, L. E. (1998). "Personality and motivational factors in computermediated foreign language communication (CMFLC).” In J.A. Muyskens (Ed.), New ways of learning and teaching: Focus on technology and foreign language education (pp. 145-197). Boston: Heinle \& Heinle.

Omaggio Hadley, A. (2001). Teaching Language in Context (3rd ed.). Boston: Heinle \& Heinle. 
Onwuegbuzie, A. J., Bailey, P., \& Daley, C. E. (2000). "Cognitive, affective, personality, and demographic predictors of foreign language achievement.” Journal of Educational Research, 94, 3-16.

Ortega, L. (1997). "Processes and outcomes in networked classroom interaction: Defining the research agenda for L2 computer-assisted classroom discussion.” Language Learning and Technology, 1, 82-93. Retrieved December 4, 2002, from .

Pelletieri, J. (2000). "Negotiation in cyberspace: The role of chatting in the development of grammatical competence.”M. Warschauer \& Kern, R. G. (Eds.), Network-Based Language Teaching: Concepts and Practice (pp. 59-86). Cambridge: Cambridge University Press.

Phillips, E. M. (1992). "The effects of language anxiety on students' oral test performance and attitudes.” The Modern Language Journal, 76, 14-26.

Scovel, T. (1978). "The effect of affect in foreign language learning: A review of the anxiety research.” Language Learning, 28, 129-142.

Sengupta, S. (2001). "Exchanging ideas with peers in network-based classrooms: An aid or a pain.” Language Learning and Technology, 5, 103-134.

Retrieved February 26, 2004, from .

Simonson, M. R., Maurer, M., Montag-Torardi, M., \& Whitaker, M. (1987). "Development of a standardized test of computer literacy and a computer anxiety index.” Journal of Educational Computing Research, 3, 231-247.

Skinner, B., \& Austin, R. (1999). "Computer conferencing—does it motivate EFL students?” ELT Journal, 53, 270-278.

Sparks, R. L. \& Ganschow, L. (2007). "Is the foreign language classroom anxiety scale measuring anxiety or language skills?” Foreign Language Annals, 40, 260-287.

Spielberger, C. D., \& Gaudry, E. (1971). Anxiety and Educational Achievement. New York: John Wiley \& Sons Australasia Pty. Ltd.

Steinberg, F. S. \& Horwitz, E. K. (1986). "The effect of induced anxiety and interpretive content of second language speech.” TESOL Quarterly, 20, 131136.

Stevens, A. \& Hewer, S. (1998). "From policy to practice and back." Proceedings of the First LEVERAGE Conference, Cambridge, 7-8. 
The Effects of Asynchronous...

Toyoda, E. (2002). "Categorization of text chat communication between learners and native speakers of Japanese.” Language Learning and Technology, 6, 8299. Retrieved March, 5, 2004, from .

Walther, J. B. (1996). “Computer-mediated communication: Impersonal, interpersonal, and hyperpersonal interaction.” Communication Research, 23, 3-43.

M. Warschauer (1996a). "Comparing face-to-face and electronic discussion in the second language classroom.” CALICO Journal, 13, 7-26.

M. Warschauer (1996b). "Motivational aspecs of using computers for writing and communication.” In M. Warschauer (Ed.), Telecollaboration in foreign language learning: Proceedings of the Hawai'i symposium. (Technical report \#12) (pp. 29-46). Honolulu, Hawai'i: University of Hawai’i, Second Language Teaching \& Curriculum Center.

Weasenforth, D., Biesengach-Lucas, S., \& Meloni, C. (2002). "Realizing constructivist objectives through collaborative technologies: Threaded discussions.” Language Learning and Technology, 6, 58-86.

Woodrow, L. J. (2006). “Anxiety and speaking English as a second language: English language speaking anxiety in a second language environment.” RELC Journal, 37, 308-328.

Young, D. J. (1986). "The relationship between anxiety and foreign language oral proficiency ratings.” Foreign Language Annals, 19, 439-445.

Young, D. J. (1990). “An investigation of students' perspectives on anxiety and speaking.” Foreign Language Annals, 23, 539-553. 


\section{About The Author}

María Isabel Charle Poza (Ed.D. in Technology Education, West Virginia University) is an assistant professor of Spanish at Lincoln University of Pennsylvania. Her research focuses on second language acquisition and language learning and technology. She has presented at numerous conferences including CALICO, NECTFL, the Horizon Wimba Desktop Lecture Series, and ACTFL. 
The Effects of Asynchronous...

\section{Appendix A}

\section{Asynchronous Computer Voice Conferencing Sample Activity}

\section{Wimba Activity 1}

Chapter 4: “El trabajo y el ocio; ¿Cómo se relaja usted?” (Work and Leisure: What do you do to relax?)

Goals (Adapted from course syllabus)

Students will speak Spanish well enough to describe, narrate, react and recommend, compare, talk about the future, and hypothesize about most familiar topics and about the resources discussed in this course.

Students will comprehend spoken Spanish with sufficient ability to grasp the main idea and most of the supporting details in short conversations--both prepared and spontaneous--that relate to topics with which you have some degree of familiarity.

\section{Objectives}

Students will speak in Spanish about work and leisure at American universities.

Pre-communication activity

Students will comprehend spoken Spanish about work and leisure at American universities.

Oct. 25 (in class, 15 minutes): Chapter 4 vocabulary about work and leisure.

The students are given sentences expressing opinions about work and leisure at American universities. They react to the opinions and share reactions with the class.

Wimba training

Oct. 25 (in class, 20 minutes): Students receive training in the use of the Wimba voice board.

Wimba activity (part 1)
Oct. 25: Wimba activity is assigned. Activity due on Oct. 29.

At their convenience, students access the Wimba voice board and answer a question that the instructor, impersonating a foreign exchange student from Spain that will come to study at WVU, has posted for the class: "Hi, I'm Alicia and I'm from Spain. I'm planning to spend a year studying psychology at WVU and I would like to have some information about American universities before I get there. I have heard that it is a lot of fun studying in the U.S. The students are always going out to clubs and sports events and don't study much, since these are their last years of 'freedom' before they enter the working world. Is that true? Work or leisure, what is more important at U.S. universities?” 
Class discussion

Oct. 29 (in class, 30 minutes): Classroom discussion about the same topic.

Wimba activity (part

2)

Nov. 1: Wimba activity is assigned. Due on Nov. 5. Students listen to the opinions of the others and determine the opinion of the majority of the class. They also write two characteristics of student life expressed in the postings. Finally, they reply to one of the opinions by saying if they agree or disagree with it, and justify their reaction.

Follow-up

Nov. 5 (in class): Students share their notes from the web board postings in order to determine the overall opinion of the class. In groups, they write a letter to the exchange student describing work and leisure at American universities. 
The Effects of Asynchronous...

\section{APPENDiX B}

\section{Wimba Anxiety Scale}

Instructions: During the past weeks, you have participated in oral conversations in Spanish using the Wimba voice board. Think about your experience when speaking in Spanish in that environment and indicate how you feel about the following statements. Select the appropriate option after each question.

Wimba Activity 1

Chapter 4: “El trabajo y el ocio; ¿Cómo se relaja usted?” (Work and Leisure: What do you do to relax?)

Likert -Scale Choices

Strongly agree

Agree

Neither Agree nor Disagree

Disagree

Strongly Disagree

1. I never feel quite sure of myself when I'm speaking Spanish in the Wimba voice board.

2. I don't worry about making mistakes in Spanish in theWimba voice board.

3. I don't worry about making mistakes in Spanish in theWimba voice board.

4. I tremble when I know I have to speak Spanish in theWimba voice board.

5. It frightens me when I don't understand what the teacher says in Spanish in the Wimba voice board.

6. I keep thinking that the other students are better at Spanish than I am when I listen to their postings.

7. In the Wimba voice board, I can get so nervous I forget things I know about Spanish.

8. It embarrasses me to answer in Spanish to other students' comments in the Wimba voice board.

9. I would not be nervous speaking Spanish with native speakers in the Wimba voice board.

10. I feel confident when I speak Spanish in the Wimbavoice board. 
11. I am afraid that my Spanish teacher will correct every mistake I make in the Wimba voice board.

12. I can feel my heart pounding when I'm going to speak Spanish in the Wimba voice board.

13. I always feel that the other students speak Spanish better than I do when I listen to their postings.

14. I don't feel very self-conscious about speaking Spanish in the Wimba voice board because the teacher is not present.

15. I don't feel very self-conscious about speaking Spanish in the Wimba voice board because other students are not present.

16. I get nervous and confused when I'm speaking Spanish in the Wimba voice board.

17. I get nervous when I don't understand every word the language teacher says in Spanish in the Wimbavoice board.

18. I'm afraid that the other students will laugh at me when they listen to my postings. 